\title{
Wstęp
}

\section{Co tu kryć?}

Jakub Momro

TEKSTY DRUGIE 2019, NR 4, S. 7-19

DOI: 10.18318/td.2019.4.1 | ORCID 0000-0003-2479-0599

Szibbolet nie szyfruje czegoś, nie jest to szyfr i szyfr wiersza; to właśnie teraz, wyłaniając się spoza sensu, w którym utrzymuje się w odwodzie, jest szyfrem szyfru, zaszyfrowanym ujawnieniem szyfru jako takiego. [...] Elipsa i cezura dyskrecji jest w nim - i nic nie można na to poradzić.

Jacques Derrida

\footnotetext{
G
} dybyśmy dziś wymyślili współczesną wersję Słownika komunałów, jednym z najważniejszych jego haseł byłaby tożsamość. Niezależnie bowiem, czy szukalibyśmy jej genealogii w romantycznych marzeniach o wspólnocie jednoczącej wszelkie byty, ale zarazem zachowującej ich wyjątkowość, czy w oświeceniowym marzeniu o jednostkowości, która realizuje się w umowie społecznej, tożsamość staje się problemem dopiero XX wieku, a nawet, można by powiedzieć, definiuje XX wiek jako taki, oraz - jak niegdyś zauważyli z przeciwstawnych pozycji Czesław Miłosz i Alain Badiou - „wiek” jako alegorię współczesności... i wszystkich jej problemów, szaleństw, zawiedzionych nadziei i niespełnionych projektów' ${ }^{1}$. Dla Flauberta i określanych

\section{Jakub Momro}

(1979), filozof,

literaturoznawca, eseista i tłumacz. Jest członkiem Kolegium Redakcyjnego dwumiesięcznika "Teksty Drugie" oraz Komitetu Redakcyjnego serii wydawniczej "Nowa Humanistyka". Niebawem ukaże się jego nowa książka, Ucho nie ma powieki 1. Dźwiękowe sceny pierwotne.

1 Por. A. Badiou Le siècle, Seuil, Paris 2005, tegoż, Francuski filozof w odpowiedzi polskiemu poecie, przeł. S. Królak, „Kronos” 2012 nr 1, s. 142-150. 
przez niego czasów tożsamość nie była kwestią do podjęcia, dlatego że spoczywała w bezpiecznym i dalekim miejscu grecko-klasycznej i scholastycznej filozofii, która nie uwzględnia człowieka w jego przebraniach i maskach, jakie celowo lub bezwiednie zakłada on na arenie przemian politycznych, ekonomicznych oraz podmiotowych. Podmiot bowiem istnieje tyleż w oficjalnym nurcie filozofii, która od czasów Kartezjusza po krytykę Kanta poszukuje takiego miejsca i momentu w poszukiwaniach ostatecznego punktu pewności i wiedzy, co w świecie intuicji i praktyk życia politycznego. Ten przedmodernistyczny świat, zanim zapanuje prawo ostatecznego odczarowania, rozpoznaje się w formach całości i prospektywnej dialektyce. Z pewnością dlatego Marks mógł zawrzeć całą myśl o sprzecznościach świata w pełni nowoczesnego w wizji kolejnych antagonizmów: społecznych nierówności oraz możliwej drogi ocalenia, czyli w emancypacji, opierającej się na reprezentacji konkretnych klas czy grup społecznych. W swym bon mocie powiadał, że - aby zrozumieć przemiany świata porewolucyjnego trzeba czytać raczej Balzaca, niż historyczne opracowania i poważne studia rodzącej się wówczas nauki socjologicznej.

To jednak wciąż prymat całości, pojmowanej nie tyle mitycznie, jako jakaś zewnętrzna sankcja metafizyczna czy transcendentna, lecz totalność form życia zabezpiecza i legitymizuje wysiłki emancypacyjne czy - znów - całkiem po prostu, rewolucję. Z tej perspektywy tożsamość nie jest ważnym zagadnieniem w społecznych formach artykulacji przeróżnych interesów (ekonomicznych, poznawczych, estetycznych). Dość spojrzeć, jak wyglądają losy materializmu po Marksie, owej dialektyki świata opierającej się na prymacie całości: pod wielu względami wczesna myśl Lukàcsa (z Historii iświadomości klasowej) jest analogiczna do tego, co Walter Benjamin próbował zrobić w Pasażach. Innymi słowy, tożsamość jako problem pojawia się wtedy, gdy - paradoksalnie - ciało społeczne cierpi na jej deficyt, to znaczy, gdy jednostki i zbiorowości nie mogą uzyskać uprawomocnienia dla własnych praktyk, kiedy zatem podmiot wiedzy przestaje bezkonfliktowo współistnieć z praktykami życia codziennego. To, rzecz jasna, problem utraty „świata przeżywanego" (Lebensweltu). Nie jest to jednak jedynie brak sposobów, pojęć i języków, które czynią doświadczenie realnym elementem egzystencji, lecz również sytuacja, w której rozpada się całość społeczna jako taka - to radykalna redukcja życia, wynikająca z o wiele bardziej jednorodnego niż można by sądzić na pierwszy rzuty oka procesu odczarowania (zarówno w planie społeczno-instytucjonalnym, jak i świadomościowym czy mentalnym). Rację mieli więc autorzy Dialektyki oświecenia, którzy ją samą widzieli nie w wyczerpaniu teoriopoznawczych modeli, lecz w zagadnieniu immanentnego życia, które nie może się wydobyć z zawrotnego, spiralnego ruchu antynomii: od absolutnej jednostkowości, owej fantazji „imienia własnego" do pragnienia życia wspólnego, w którym więź i relacja są czynnikami najważniejszymi. Rozum krytyczny stawia nas oto przed alternatywą: albo przejmująca 
samotność lub resentymentalna i narcystyczna autarkia, albo struktura wspólnoty, kierowana inercją siły i determinizmem nagiej przemocy, wobec której bezradny pozostaje wszelki dyskurs.

Toteż nietrudno zrozumieć, że dla Horkheimera i Adorna oświecenie to proces rozpatrywany nie chronologicznie, lecz anachronicznie, to znaczy rozpoczyna się on od analizy działań i pasywności Odyseusza - obie formy służą egzystencjalnemu samozachowaniu. Niezależnie od tego, jak bardzo defensywna, a nawet katastroficzna jest to wizja, opiera się na niezwykle rzadkim - i wtedy, i dziś - połączeniu wyobraźni epistemologicznej z polityczną. Kiedy już na pierwszych stronach dzieła czytamy o nieszczęsnej dialektyce podmiotowego zwycięstwa nad naturą, za którym niczym cień pojawia się wyobcowanie ze świata, to patrzymy zarazem na scenę rodzenia się (nowoczesnej) zasady tożsamości i radykalnej inności, które działają, stając się rodzajem maszyn, czy - używając Foucaultowskiego pojęcia - urządzeń adaptacyjnych. Mówią o tym niemal wszystkie istotne epizody eposu o Odysie: "gra w Nikogo", scena z Syrenami, oscylacja między Scyllą a Charybdą. Czy chodzi tu tylko o dość prymitywny spryt językowy czy teoriopoznawczy? Adorno powiada, że narodziny tożsamości to rana lub trauma nowoczesnego świata, w którym pojęcia nie służą krytycznej samowiedzy, a figury i metafory języka poezji znienacka przeobrażają się w puste nazwy, obrazy i obiekty spektaklu kapitalistycznej i inercyjnej ekonomii wymiany. Nawet jeśli, jako się rzekło, pominąć ten katastroficzny ton, widać wyraźnie w jaki sposób tożsamość stanowi ślepą plamkę współczesności, rodzaj martwego punktu, w którym doświadczenia oraz utopie estetyczne i polityczne zasysa prawo, które Adorno wyraził w sposób następujący: wszystko jest tożsame ze wszystkim, nic nie jest tożsame z samym sobą².

Tożsamość wydaje się fetyszem albo czystą tautologią. Hegel powiadał, że logika bez zapośredniczenia jest pusta; nic nie znaczy i nic nie daje żywym rachunek syntez, alternatyw, koniunkcji oraz dysjunkcji jeśli nie dotknie jakiegoś nieznanego elementu myślenia. Tożsamość nie może zatem być procesem (w tym sensie, w jakim mówimy o tożsamościach narodowych, klasowych, mniejszościowych), bowiem jej społeczna obecność wynika z fałszywej ekstrapolacji problemu logicznego na rzeczywistość społeczną. Skoro tak, to sama tożsamość staje się, najczęściej niechcianym i odrzucanym, idolem, który określał w dużej mierze niemal wszystkie postnowoczesne języki. Dobrym przykładem tej dynamiki pozostaje socjologiczne pisarstwo Zygmunta Baumana, który w niemal każdej książce proponował nowe określenie tożsamości (ze słynnym „płynnym” jej kształtem na czele), ale też wraz z kolejnymi metaforami siła samej tożsamości gasła.

2 Por. M. Horkheimer, T.W. Adorno, Dialektyka oświecenia. Fragmenty filozoficzne, przeł. M. Łukasiewicz, Krytyka Polityczna, Warszawa 2010, s. 17. 
Czy zatem pytanie o jednoznaczność subiektywnie odczuwanego życia, o to, kim i z kim współistnieję, to kwestie nieistotne? Wydaje się, że jest przeciwnie. Tyle że problemy te lokują się w zupełnie innych, niż tożsamościowe, miejscach. Najczęściej pytamy o to, co zakreśla przestrzeń naszych sekretów, enigmatycznych sfer, w których myślenia nie sposób odłączyć od języka, praktyk życia, ale też od koniecznych chwil alienacji, które działają niekoniecznie destrukcyjnie, raczej - otrzeźwiająco. Ten rodzaj wielościowej dialektyki pozwala uchylić pytania o relacyjność podmiotu i niewspółmiernej wobec niego inności, jak również poważnie osłabić proklamacje o panowaniu dyskursu. Oba te stanowiska absolutyzują i, by tak rzec, fiksują pewien moment w doświadczeniu, tak jakby należało szukać ratunku w tym, co znajduje się poza immanentnym życiem. Z tego punktu widzenia nie ma specjalnej różnicy między idealistyczną i metafizyczną filozofią Levinasa a wczesną koncepcją archeologii wiedzy Foucaulta - w pierwszej ekstatyczna i erotyczna asymetryczna relacja z Innym jest niemal wprost religijna, w drugiej epistemologiczne pytanie o to, kto mówi w tekście, zostało zastąpione wyobcowującą dynamiką anonimowego dyskursu³.

Tymczasem właśnie to pytanie, które z taką nonszalancją Foucault odrzuca, trzeba podtrzymać, a nawet rozszerzyć jego zasięg. Prowadzi ono nie w kierunku znanych sfer i napięć między nimi: wnętrza i zewnętrza, świadomości i zapośredniczenia, partykularyzmu i wspólnoty, pojęcia i obrazu, lecz tam, gdzie te znane relacje osiągają swój kres i rodzą się nowe formy życia. Stanowią one wyzwanie, które nie polega już na tym, jak wypowiedzieć własną odrębność, lub jak w ogóle zaznaczyć siebie w świecie i jak zdefiniować warunki emancypacji, lecz na tym, by doznanie świata w jego różnych modalnościach czasu otworzyło nas na błąd, pomyłkę, inność, która nie zależy już od żadnego bożka tożsamości. Prymat tego, co identyczne jako ideał teoriopoznawczy, rozciągający się na całą wiedzę o człowieku, nie tylko ogranicza nas egzystencjalnie, ale również (może nawet przede wszystkim) formalnie. Czy nie jest tak, że np. wiele kłopotów z dzisiejszą humanistyką bierze się z tej założycielskiej mistyfikacji, polegającej na tym, że aby pomyśleć filozofię polityki, etykę czy estetykę zakłada się jako coś oczywistego i zarazem ideologicznie nieuchwytnego nieuchronny determinizm tożsamości jako całkowitej swojskości (co widać w linii od Heideggera do Sloterdijka), udomowienia, w którym to, co nasze (w tym także przywłaszczone) ma pozostać ukryte w kokonie niewidocznej i nieodczuwalnej dla innych prawdy? W tym znaczeniu neurotyczna i lękowa fikcja własności i niedostępności oraz bezbrzeżnej i bezwarunkowej afirmacji inności to dwie strony tej samej, niekrytycznej twarzy naszych czasów.

Tak często wieszczone w drugiej połowie XX wieku najrozmaitsze końce i kresy odznaczają się dynamiką gestów upodmiotowienia, opierającą się na potrzebie

3 Por. M. Foucault Porządek dyskursu, przeł. M. Kozłowski, słowo/obraz terytoria, Gdańsk 2002. 
wyznaczenia ostatecznej granicy określonej formy życia (kres antropologiczny, osłabienie instancji mówienia, kolaps komunikacyjny, upadek polityki i pojęcia polityczności w tradycyjnym sensie i konieczność rewolucji). Co więcej, ten żywioł różnicowania stanowi rodzaj bezimiennego spadku: kiedy dziś zastanawiamy się nad końcem świata jaki znamy, lub nad naszymi związkami z naturą, zwierzętami czy tym, co nieorganiczne, granice muszą pozostać uchwytne nie tylko po to, oczywiście, by restaurować antymodernistyczne nostalgie za autentycznym życiem, lecz po to by - jak mówił niezawodny pod tym względem Adorno - "naprawić krzywdę, którą podmiot wyrządził temu, co nietożsame ${ }^{\prime \prime}$. Ten zadziwiająco niedialektyczny gest polega w gruncie rzeczy na prostym odwróceniu: to, co heterogeniczne skrywa jakąś tajemnicę, którą należy odkryć; to już nie subiektywność jest dla samej siebie zagadką, lecz jest nią racjonalność lub nierozumność zewnętrza - wrogiego lub po prostu obcego, nieznanego świata. A co, jeśli nie ma nic wewnątrz, ani na zewnątrz? Co, jeśli katastrofa naturalna, choć przybiera niesłychane rozmiary i bezustannie nam pokazuje, że świat dzisiejszej akceleracji przestaje mieć cokolwiek wspólnego z naszymi apokaliptycznymi wyobrażeniami o końcu czasów, „jest" ulokowana w zupełnie nieznanym nam miejscu, rządzi się niezbadaną ontologią? Co, jeśli dialektyka oświecenia działa w najgorszy z możliwych, niesłychanie opresyjny sposób, wraz z odczarowaniem wzrastającym nie w nowych sposobach myślenia, lecz w porządku pierwotnego fetyszyzmu? Co, jeśli nasz świat nie skrywa już żadnych sekretów, nie dlatego jednak, że nauka, poznanie, sztuka czy literatura nie są wynalazcze, przeciwnie: dlatego, że pozostają więźniami inwencyjności, rozumianej jako kapitalizowanie każdej, nawet najdrobniejszej myśli? Nic nie strzeże już sekretów, bo nie ma granic dla wyobcowania, które działa jak ideologia w czystej postaci, niezależnie od tego, czy mówimy o czytaniu, filozofowaniu czy refleksji nad życiem w ramach określonych instytucji wiedzy. Trzeba tu być jednak ostrożnym. Mowa bowiem o wyobcowaniu, które zawsze przychodzi „z zewnątrz". Tymczasem naszemu myśleniu potrzebna jest dobrowolna alienacja - moment przesilenia, w którym być może z radykalnej krytyki tego, co istnieje i tego, co pozostaje ukryte, jak mówił pięknie Kant „,,w głębinach duszy ludzkiej”, , wydobędzie się nowość świata, dla którego jeszcze nie mamy nazwy.

Myślę, że ta ogólna rama pozwala dostrzec szczegóły, które - często - rozstrzygają o naszych egzystencjalnych, artystycznych, poznawczych i politycznych formułach zaangażowania. Jedną z nich (wcale niedominującą) jest psychoanaliza, której nie traktuję tu jako szkoły czy instytucji myślenia, lecz jako pewną postawę, która przemieszcza racjonalność poza opozycję sekretu i jawności. Właśnie dlatego analiza (rozumiana

4 Por. T. W. Adorno Dialektyka negatywna, przeł. K. Krzemieniowa, PWN, Warszawa 1986, s. 202.

5 Por. I. Kant Krytyka czystego rozumu, przeł. R. Ingarden, Warszawa 1957, t. I, s. 291. 
zarówno w aspekcie klinicznym, jak i kulturowym) w ostatecznym rozrachunku ma nam pozwolić na emancypację poza danym systemem (leczenia/lub i refleksji). Zasadnicze pytanie, zwrotnie łączące analityka z pacjentem i krytyka z jego światem, okazuje się w gruncie rzeczy bardzo proste: kiedy skończy się analiza? Jak rozpoznam, że jestem zdrowy? Czy odkrycia mniej lub bardziej traumatycznych scen pierwotnych pozwalają odnaleźć się w formach sublimacji, które są zarazem subiektywnie "moje”, a przecież w równej mierze powszechne? To bodaj w tym miejscu objawia się genialna intuicja Freuda, dzięki której impuls psychoanalityczny i dziś pobudza refleksję antropologiczną. To rozpoznanie fatalnego narcyzmu człowieka, który wywłaszcza go z niego samego, pozostaje nietwórczy i uciążliwy, regresywny i nieprzezwyciężalnie lękowy; to ten gest odważnej deziluzji otwiera możliwość identyfikacji z własnym symptomem, który nie ma żadnej substancji - tak jak trauma odtwarzana, towarzysząca przemierzaniu własnych fantazmatów i wreszcie ich wypowiedzeniu, co prawda nie przestaje być jednostkowym, cielesno-tkankowym zranieniem, lecz nie definiuje już głębokiej, skrywanej tożsamości. Język snu to - biorąc pod uwagę dwuznaczność niemieckiego Traum - także owa rana, którą dyskurs, ani wewnętrzny ani zewnętrzny, wyraża w imię życia zapośredniczonego. Niczym w teatrze Brechta, śniący komunikuje się poprzez stwarzany przez siebie dystans, nasycany przez zmysłowość, sensoryczność, cielesność, staje się" przykładem" czy psychopatologicznym „typem"tylko na moment samowiedzy oraz uznania powszechności własnego losu i własnej pozycji. U kresu analizy sekretna trauma, choć „się" wypowiada, nie niszczy subiektywności, lecz powołuje jej dojrzalszą formę, w której - co trafnie i bezkompromisowo pokazał z kolei Lacan - symptom nie ma w sobie nic z istoty, a więc nie łudzi nas jakąś tożsamościową prawdą, lecz jest pustką, z której rodzi się nasza podmiotowość - pustką bez sekretu, bez tajemnicy, bez konieczności metafizycznych lub lingwistycznych gier językowych.

Uznanie tej pustki konstytuuje świat nowoczesnego maranizmu. Główni bohaterowie niniejszego numeru „Tekstów Drugich" to ich późnonowoczesne złożone, literackie wcielenia, w dodatku tropione przez autorów w literaturze polskiej, gdzie historyczne uwikłania stanowią jeszcze większe wyzwanie tyleż interpretacyjne, co etyczne. Współcześni marani to, oczywiście, bardzo dalecy wnukowie nie tylko późnośredniowiecznych konwertytów żydowskich, których władza (inkwizycyjna, a następnie siła ludu powodowanego antysemityzmem) nieustannie podejrzewała o ukryte praktykowanie rzekomo porzuconego judaizmu. Co znaczy taka figura dzisiaj? Co prawda starcie oświecenia i wiary przyniosło rezultat w postaci hybrydycznej i heteronomicznej myśli, ale zbyt szybko utonęła ona w rozważaniach czysto uniwersalnych. Powszechność (wiary lub ateizmu) zestawiona $\mathrm{z}$ "kryptycznym” modelem egzystencji to elementy nierefleksyjnej maszyny interpretacji, z której na koniec wynika, że wszystko co mamy - w języku, w myśli - jest nieredukowalnie religijne. Ale czy taki maranizm, 
w którym „życie ukryte” toczy się pod znakiem innych zagrożeń, w dużej mierze nieopisujących już nawet czasów „po końcu” religii, może stać się dziś interesujący? Czy może raczej chodzi o ocalenie życia poza zasadą heteronomii i autonomii, to znaczy poza zewnętrznym przymusem wyznania (powiedz nam kim jesteś, a my powiemy kim możesz być), lub podporządkowania (jak w komunistycznym odczytaniach Pawłowego uniwersalizmu, gdzie nienaruszalność i jednoznaczność wydarzenia unieważnia życie w imię tyleż namiętnej, co indyferentnej „wierności")? ${ }^{6}$ I to nie wydaje się trafione.

O tych naszych współczesnych wątpliwościach mówią najtragiczniejsze bodaj losy nowożytnego filozoficznego marana, czyli Uriela Acosty, którego autobiografia, Wizerunek własny żywota, pokazuje jego liczne wolty światopoglądowe, wymuszone, rzecz jasna, przez opresyjną władzę kościoła katolickiego z jednej strony oraz wspólnoty żydowskiej z drugiej’. Zasadniczym powodem odrzucenia i wynikłych z niego cierpień Acosty nie była nawet jego instytucjonalna świeckość jako wyznawcy, czy w konsekwencji - obywatela i wypływająca z tego wielokrotna nieprzynależność, co wyjątkowość projektu intelektualnego. Opierał się on na zasadzie nowego życia racjonalnego, które ustanawia porządek egzystencji indywidualnej i zbiorowej przez gesty sekularyzacji, od której nie ma już odwrotu. Z dzisiejszej perspektywy nauka o człowieku Acosty wyznacza kierunek, w którym zeświecczenie obejmuje nie tylko życie polityczne, ale dotyka polityki pisma - wyrażania i zaznaczania siebie w różnych narzeczach językowych. Pismo marańskie to nie maska, chroniąca przed zniewagą i śmiertelną przemocą, które nadchodzą od strony tępych instytucji i wyrastających z nich bezmyślnych dyskursów, ustanowionych na dualizmie swojskiej tożsamości i wrogiej obcości, lecz świat "życia własnym życiem".

Nietrudno zrozumieć zatem, że postawa Acosty pozostaje tak ważna dla zrozumienia całego projektu geometrycznej i afektywnej etyki Spinozy, którego los w gminie żydowskiej w powyższym sensie był powtórzeniem losu portugalskiego marana. Zarazem jednak chodzi tu o coś więcej, o coś, co dotyka nowoczesnej rewolucji myślowej. Acosta, który z uporem podkreślał mistyfikacyjny i ideologiczny wymiar dogmatu nieśmiertelności duszy, traktując go jako widmo dosłownej lektury Pisma, zarazem wyznaczał horyzont myślenia immanencji, wyrzekającej się metafizycznych fantazji

6 Por. A. Badiou Święty Paweł. Ustanowienie uniwersalizmu, przeł. J. Kutyła, P. Mościcki, Ha!art, Krytyka Polityczna, Warszawa 2007; S. Žižek Kukła i karzeł: perwersyjny rdzeń chrześcijaństwa, przeł. M. Kropiwnicki, Branta, Bydgoszcz-Warszawa-Wrocław 2006.

7 Por. U. Acosta Wizerunek własny żywota, przeł. K. Dresdner, PIW, Warszawa 1960, s. 30: „Doszedłem w końcu do przekonania, że Zakon nie jest dziełem Mojżesza, tylko wymysłem ludzkim, jako mnóstwo rzeczy na świecie. Wiele bowiem z tych ustaw kłóciło się z prawem natury, a przecie nie mógł Bóg, stwórca natury, sobie samemu przeczyć; sam by zaś sobie przeczył, gdyby ludziom czynić kazał rzeczy niezgodne z naturą, za której sprawcę był poczytywany". 
na rzecz racjonalności wpisanej w życie naturalne. W tym miejscu rozpoczyna Spinoza. Owa natura (w obydwu odmianach: „tworzącej,", natura naturans i „stworzonej”, natura naturata) nie jest wsobna i samowystarczalna, lecz urzeczywistnia się wyłącznie poprzez afektywne poruszenie oraz siłę ekspresji. To natura domaga się systemu teoriopoznawczego, uwzględniającego jedność i konieczność mówienia. Spinoza okazuje się maranem w nowoczesnym sensie nie dlatego, że myśli w kategoriach jakiejś unitarności bytu i języka oraz pojęć, lecz dlatego, że afektywne życie nigdy nie staje się wybrakowane. Egzystencjalna siła etyczna polega właśnie na wolności ekspresji, niezależnie od porządków obowiązującej teologii politycznej czy normatywnych zasad kulturowych, estetycznych i poznawczych. Dzisiejszy maranizm, jak ten literacki prezentowany w niniejszym numerze „Tekstów Drugich", religię traktuje jako rodzaj heterologii, gdzie, zgodnie z tym co mówi Spinoza, jednocześnie i nierozłącznie wyrażają się substancje, atrybuty oraz istoty.

Za współczesną restytucję dzieła Spinozy, pojmowanego nie tylko jako projekt filozoficzny, lecz także polityczny, bez wątpienia odpowiada Gilles Deleuze. W jego interpretacji, jako się rzekło, prymat immanencji jest bezdyskusyjny i właśnie z tego powodu współczesny maranizm spinozjański wygląda tak intrygująco. Sekret nie polega tu na intencjonalnym czy psychoteologicznym zakrywaniu i odsłanianiu indywidualnej prawdy przed zbiorowością czy wobec tradycji poznawczej, lecz polega na znalezieniu sposobu dotarcia do przyczyny immanentnej (a nie np. odtworzeniu zasady teologicznej) - byt wyraża „się", na mocy własnego życia, poprzez zmiany intensywności odbieranych i wytwarzanych wrażeń oraz afektów. Toteż sekret mieści się nie w gotowym skrypcie języka, lecz w zagadce życia nierozdzielnego z jego własną ekspresyjnością - pytanie nie brzmi: co pojęcie lub metafora mogą wyrazić, ale: co niewyrażalnego, enigmatycznego zawiera się w tym, co tworzy akt i siłę ekspresji. To wielki temat współczesnej sztuki i filozofii.

To jednak nie koniec marańskich przygód nowoczesnego świata. Dla wszystkich autorów z niniejszego numeru podstawową figurą nowoczesnego myślenia i pisania spod tego znaku pozostaje Jacques Derrida. Niewątpliwie ten największy współczesny filozof pisma wykazywał, zwłaszcza w ostatnich dwudziestu latach swej działalności, szczególną wrażliwość na problemy sekretu, wyjścia i opuszczenia, doświadczeniowego pustynnienia i możliwości postreligijnych czy, jak sam to określał, quasi-mesjańskich wspólnot. Tak jak w przywołanym w epigrafie Derrida gra z sekretem na dwóch poziomach: na jednym sekret jest i przejawia się "na zewnątrz", jako (jednostkowe lub mnogie) doświadczenie, na drugim - tak jak obrzezanie zaznacza się w fakturze

8 Por. G. Deleuze Spinoza et le problème de l'expression, Minuit, Paris 1968, tegoż, Spinoza. Filozofia praktyczna, przeł. J. Brzeziński, PWN, Warszawa 2014. 
języka jako niezacieralne znamię, tak sekret znaczenia czy metafory staje się zdarzeniem, regulowanym przez system poetycki i tradycję literacko-estetyczną. W pięknym filmie biograficznym, o wieloznacznym tytule, D'aillieurs, sugerującym, co ważne w tym kontekście, "bycie z boku”, „z drugiej strony" oraz czysto kolokwialne „poza tym”, „zresztą", reżyserka Safaa Fathy, pokazuje Derridę odwiedzającego różne marańskie miejsca, ale jedno z nich wydaje się szczególnie ważne9. W Toledo filozof zatrzymuje się przy słynnym obrazie El Greka Pogrzeb hrabiego Orgaza, wskazując na jego heterogeniczność czysto formalną i estetyczną, ale też - co istotniejsze - czasową, w której żywy podmiot, żyjący „z boku”, przegląda się w symbolicznym obrazie samej śmierciº. I właśnie wtedy filozof podkreśla siłę pisma, rozpoznaje imperatyw mówienia „wobec” figury martwego ciała. Pismo, choć radykalnie skończone, to w swej materialności, a nawet śladowej szczątkowości, wskazuje na konieczność artykulacji i ekspresji tego, co niewidoczne w świecie kierowanym regułami rozumienia, widzenia i komunikacji, To pisanie bowiem jest miejscem oporu, sprzeciwu, wywrotowej mocy przeciwko wszelkim odmianom dogmatyzmu i redukcji wielości form życia. Tak, pismo ostatecznie okazuje się morfologią świata, przemienianego w sekret, który nie podlega prostej opozycji prywatne-publiczne, lecz trafia w samo sedno praktyk mówienia i pisania nie można pozbyć się przemocy zewnętrznego świata, ale zarazem konieczność jej osłabiania pozostaje niezbywalna".

Być może z tego powodu Derrida tak bardzo upodobał sobie "dar", nawet nie tyle jako problem filozoficzny czy antropologiczny, ale jako rodzaj dojścia do zagadki sekretu literatury. Z tej perspektywy staje się ona życiodajną fikcją, która w sensie ścisłym nie mówi nic, lecz strzeże swej tajemnicy.To, by tak rzec, beztreściowa formalizacja. Brzmi abstrakcyjnie? Z pewnością, ale tylko do pewnego stopnia. Aby rozjaśnić tę formułę, Derrida używa poręcznej i pięknej metafory literatury jako meteoru. Figura ta wchłania wiele funkcji, jakie literatura sprawuje: dotyku, eteryczności, czasowości, zjawiskowości ${ }^{12}$. Wszystkie te własności wskazują na przygodny charakter literatury jako sekretu. Oznacza to jednak coś jeszcze. Literatura jest wielością nie tylko w porządku epistemologicznym, nie tylko mówi o rzeczywistości „na nieskończenie wiele sposobów”, by użyć sformułowania samego filozofa, ale pokazuje, że owa formalna pustka to wyraz

9 Bardzo ważnym kontekstem jest tu niezwykła książka: J. Derrida, C. Malabou La contre-allée, La Quinzaine littéraire, Paris 2009.

Ten wątek przenika jeden z najbardziej osobistych tekstów Derridy. Por. J. Derrida Obrzezania (Circonfession) w: G. Bennington, J. Derrida Jacques Derrida, przeł. V. Szydłowska-Hmisssi, Genesis, Warszawa 2009, s. 121-128.

11 Por. J. Derrida, M. Ferraris A Taste for a Secret, trans. G. Donis, Polity, Cambridge 2001. 
sprzeciwu wobec traumatycznego pojmowania pisma. Jest ono wymierzone przeciwko Jednemu (plus qu'Un), a więc przeciwko takiemu zranieniu (znów: prywatnemu i publicznemu zarazem), które staje się skamieniałym milczeniem, sekretem absolutnym, zabijającym każdą ekspresję i ostatecznie podległym brutalnemu panowaniu tej czy innej formy politycznego zniewolenia. Jeśli zatem literatura faktycznie jest meteorem, wpadającym w powietrzny wir naszych reprezentacji, sposobów rozumienia i praktyk analitycznych, to pojawiając się na moment jako zjawisko ściśle fizyczne, materialne, ostatecznie dotyka ziemi, empirycznego świata. Ale, rzecz jasna, literatura jako meteor jest także wyobrażeniem przyszłości - dialektyki determinizmu i przypadku, nadziei i lęku, myślenia i teoriopoznawczego nihilizmu, przynajmniej po części definiującego nasze języki i światopoglądy. Toteż w bodaj najważniejszym pod tym względem tekście: Jednojęzyczność innego, czyli proteza oryginalna, Derrida mówi - wreszcie - wprost: bycie współczesnym maranem oznacza wejście w logikę „asfikcji", czyli uznanie, że istnienie to stan pragnienia prze-życia (sur-vivre) w piśmie i poprzez pismo ${ }^{13}$. Czyż nie tak należałoby rozumieć pozornie pretensjonalną uwagę filozofa, że zasadniczym celem jego projektu dekonstrukcji jest odciśnięcie własnego znamienia we francuszczyźnie, którą tak kochał, choć - jak to bywało najczęściej - była to miłość bez wzajemności? To wbrew pozorom odwrotność narcystycznego gestu pisarza. Derrida bowiem rozbraja sekret pisania i ekspresji jako czegoś osobnego, wskazując, że wszelkie akty językowe i pojęciowe, muszą zderzyć się z Prawem, czyli wyjść poza zasadę przyjemności. Piszemy w końcu „w imię czegoś," nawet jeśli (dla Derridy: przede wszystkim) to "coś" pozostaje zupełnie nieuchwytne.

Literatura to forma współ-dzielenia życia. Z pewnością to miał Derrida na myśli, gdy medytując nad, skądinąd na wskroś marańskim, problemem gościnności i wrogości, parafrazując hasło Boskiego Markiza, tytułował jeden z tekstów: Kosmopolici wszystkich krajów, jeszcze jeden wysiłek!14 Patronami tego myślenia, przywracającego "ukryty" wymiar wspólnoty pisania, myślenia, życia i śmierci, są Georges Bataille i Maurice Blanchot ${ }^{15}$. Pierwszy szukał szczególnego punktu w literaturze, filozofii i sztuce, gdzie amorficzność doznań spotykałaby się ze ścisłością refleksji, zaś drugi - w swej późnej

13 Por. J. Derrida Jednojęzyczność innego, czyli proteza oryginalna, przeł. A. Siemek, „Literatura na Świecie"1998 nr 11-12, s. 94-111.

14 Por. J. Derrida Kosmopolici wszystkich krajów, jeszcze jeden wysiłek!, „Literatura na Świecie” 1998 nr 11-12, s. 115-133.

Por. G. Bataille Część przeklęta oraz Ekonomia na miarę wszechświata. Granica użytecznego, przeł. K. Jarosz, KR, Warszawa 2002; M. Blanchot La Communauté inavouable, Minuit, Paris 1983, tegoż, L'Amitié, Galimard, Paris 1971, tegoż, Le pas au-delà, Gallimard, Paris 1973; J.-L. Nancy La pensée dérobée, Galilée, Paris 2001, tegoż, Rozdzielona wspólnota, przeł. M. Gusin, T. Załuski, Wydawnictwo Naukowe Dolnośląskiej Szkoły Wyższej, Wrocław 2010. 
refleksji nad judaizmem (motywowanej w dużej mierze ekspiacją za swój międzywojenny antysemityzm i haniebne teksty pisane podczas II wojny), pokazuje "niewidzialną" myśl w ciągłym zderzeniu ze zbiorowym doświadczeniem historycznej katastrofy. Dla Blanchota tak wygląda przyjaźń, schowana w nieskończonej negatywności i neutralności. Ale przecież ten mroczny wymiar stał się punktem wyjścia dla powstawania wspólnot, najczęściej odległych od ściśle teologicznych czy postsekularnych wyobrażeń społecznych - wspólnot chropawych, niedających się scalić. Jean-Luc Nancy mawiał, że są to rozdzielone formy współistnienia, które rodzą się w koniecznym dystansie oraz ciszy, choć równocześnie pozostają łączliwe niczym tkanki jednego ciała, corpusu.

Te przygody maranizmu jako figury sekretności pokazują coś jeszcze, co - jak sądzę - w dużej mierze rozstrzyga o aktualnym statusie nauk o człowieku. To pytanie o życie, którego kruchość należy ocalić. Wbrew pozorom to nie tylko etyka dla pięknoduchów nomen omen ukrytych w murach akademii, lecz najpierw kwestia teoriopoznawcza: gdzie mieszczą się sekrety tekstów i ludzi? W jakich sferach kultury i nauki czai się zło, a gdzie język poświadcza dobrowolne wygnanie? Co dzieje się z ekspresją, której nie reguluje żadna norma? Dlaczego sekrety mają w ogóle zostać wypowiedziane, czy nie mogą istnieć niczym wieczne elipsy? Kto lub co o tym wszystkim rozstrzyga? Jedną z najpiękniejszych i najpełniejszych odpowiedzi można odnaleźć w koncepcji „literatury mniejszej" Deleuze'a i Guattariego, pozornie tak odległej od marańskich problemów. Jednak to z takiej zapośredniczonej perspektywy widać dopiero wagę tekstów, które wypełniły numer „Tekstów Drugich". Jak mówią autorzy Kapitalizmu i schizofrenii:

Iluż ludzi żyje obecnie w języku, który nie należy do nich? Ilu nie zna języka, albo zna niedostatecznie? Ilu źle zna język oficjalny, choć musi go używać? To problem imigrantów, a przede wszystkim dzieci. Problem mniejszości. Problem naszej literatury, ale także nas wszystkich: jak wyswobodzić język przynależny literaturze mniejszej, zdolny do pogłębienia języka jako takiego i splecenia go w nową linię rewolucyjną? Jak stawać się nomadą i imigrantem i zarazem Cyganem własnego języka?16

\section{Literatura:}

Badiou A. Le siècle, Seuil, Paris 2005.

Badiou A. Francuski filozof w odpowiedzi polskiemu poecie, przeł. S. Królak, "Kronos” 2012, S. 142-150.

16 G. Deleuze, F. Guattari, Kafka Pour une littérature mineure, Minuit, Paris 1975, s. 35. Przekład polski, G. Deleuze, F. Guattari, Kafka Ku literaturze mniejszej, przeł. A.Z. Jaksender, K.M. Jaksender, Eperons-Ostrogi, Kraków 2016, s. 97. 
Derrida J. Kosmopolici wszystkich krajów, jeszcze jeden wysiłek!, "Literatura na Świecie” 1998, nr 11-12, s. 115-133.

Bataille G. Część przeklęta oraz Ekonomia na miarę wszechświata. Granica użytecznego, przeł. K. Jarosz, KR, Warszawa 2002.

Blanchot M. La Communauté inavouable, Minuit, Paris 1983.

Blanchot M. L'Amitié, Galimard, Paris 1971.

Blanchot M. Le pas au-delà, Gallimard, Paris 1973.

Nancy J.-L. La pensée dérobée, Galilée, Paris 2001.

Nancy J.-L. Rozdzielona wspólnota, przeł. M. Gusin, T. Załuski, Wydawnictwo Naukowe Dolnośląskiej Szkoły Wyższej, Wrocław 2010.

Deleuze G. Guattari F., Kafka. Ku literaturze mniejszej, przeł. A.Z. Jaksender, K.M. Jaksender, Eperons-Ostrogi, Kraków 2016.

Derrida J. Obrzezania (Circonfession) w: G. Bennington, J. Derrida, Jacques Derrida, przeł. V. Szydłowska-Hmisssi, Genesis, Warszawa 2009, s. 121-128.

Derrida J. Ferraris M., A Taste for a Secret, trans. G. Donis, Polity, Cambridge 2001.

Derrida J. Donner la mort, Galilée, Paris 1999, s. 163-208.

Derrida J. Jednojęzyczność innego, czyli proteza oryginalna, przeł. A. Siemek , Literatura na Świecie" 1998 nr 11-12, s. 94-111.

Deleuze G. Spinoza et le problème de l'expression, Minuit, Paris 1968.

Deleuze G. Spinoza. Filozofia praktyczna, przeł. ). Brzeziński, PWN, Warszawa 2014.

Derrida J., Malabou C. La contre-allée, La Quinzaine littéraire, Paris 2009.

Badiou A.Święty Paweł. Ustanowienie uniwersalizmu, przeł. J. Kutyła, P. Mościcki, Ha!art, Krytyka Polityczna, Warszawa 2007.

Žižek S. Kukła i karzeł: perwersyjny rdzeń chrześcijaństwa, przeł. M. Kropiwnicki, Branta, Bydgoszcz-Warszawa-Wrocław 2006.

Acosta U. Wizerunek własny żywota, przeł. K. Dresdner, PIW, Warszawa 1960.

Adorno T.W. Dialektyka negatywna, przeł. K. Krzemieniowa, PWN, Warszawa 1986, s. 202. Kant I. Krytyka czystego rozumu, przeł. R. Ingarden, Warszawa 1957.

Foucault M. Porzqdek dyskursu, przeł. M. Kozłowski, słowo/obraz terytoria, Gdańsk 2002. Horkheimer M., Adorno T.W. Dialektyka oświecenia. Fragmenty filozoficzne, przeł. M. Łukasiewicz, Krytyka Polityczna, Warszawa 2010. 


\section{Abstract}

\section{Jakub Momro}

JAGIELLONIAN UNIVERSITY, CRACOW

What's There to Hide?

This article introduces analytical tools to describe contemporary Marranism - tools that are different from those which draw on the dialectics of secularisation, or, more broadly speaking, disenchantment and the determinism of late-modern post-secularism. Momro builds on the fundamental critique of the concept of identity as doxa within the humanities and draws on the materialism that is inherent in psychoanalysis as well as in contemporary Spinozism to demonstrate how the marrano transforms from a figure of religious identification or its absence into the heteronomic "minority subject" we know today - one that constantly searches for a place and time for a suitable form of expression.

\section{Keywords}

modernity, identity, Marranism, secret, minority, community, immanence 